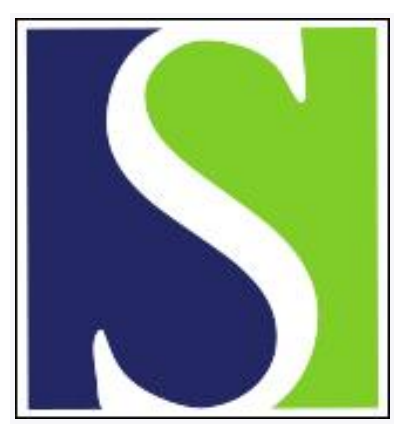

Scand J Work Environ Health 1990;16(5):363-371

https://doi.org/10.5271/sjweh.1772

Issue date: 00 Oct 1990

Influence of indoor climate on the sick building syndrome in an office environment. The Danish Indoor Climate Study Group. by Skov P, Valbjorn O, Pedersen BV

Affiliation: Clinic of Occupational Medicine, Rigshospitalet, University of Copenhagen, Denmark.

This article in PubMed: www.ncbi.nlm.nih.gov/pubmed/2255877 


\title{
Influence of indoor climate on the sick building syndrome in an office environment
}

\author{
by Peder Skov, MD, ${ }^{1}$ Ole Valbjørn, MSc, ${ }^{2}$ Bo V Pedersen, $\mathrm{MSc},{ }^{3}$ \\ the Danish Indoor Climate Study Group ${ }^{4}$
}

\begin{abstract}
SKOV P, VALBJØRN O, PEDERSEN BV, THE DANISH INDOOR CLIMATE STUDY GROUP. Influence of indoor climate on the sick building syndrome in an office environment. Scand $J$ Work Environ Health 1990;16:363 - 71. The influence of indoor climate factors on symptoms of the sick building syndrome was investigated in Greater Copenhagen, Denmark. Altogether, 2369 office workers in 14 buildings, where indoor climate measurements were made, filled out a questionnaire. Multivariate logistic regression analyses of the multifactorial effects on the prevalence of work-related mucosal irritation and workrelated general symptoms among the office workers showed that the concentration of macromolecular organic floor dust, the floor covering, the number of workplaces in the office, the age of the building, the type of ventilation, and two easily recognizable factors, the shelf factor and the fleece factor, were associated with the prevalence of symptoms.
\end{abstract}

Key terms: general symptoms, mucosal irritation, office workers.

Complaints about discomfort and health effects in relation to work in nonindustrial workplaces have increased during the last 10 to 15 years. In 1983 the World Health Organization defined the concept of the sick building syndrome (1) as being characterized by a high frequency of irritative symptoms of the eyes, nose, throat and lower airways, skin reactions, nonspecific hypersensitivity, mental fatigue, headache, nausea, and dizziness among persons staying in a particular building. The symptoms are experienced as work-related as they typically grow worse during the workday in the building and disappear or diminish after the person has left the building. The etiology of this syndrome is currently not fully understood.

Only a few epidemiologic studies have been made on the sick building syndrome (2-7). Complaints about work-related irritation of the mucous membranes and work-related general symptoms such as

${ }^{1}$ Clinic of Occupational Medicine, Rigshospitalet, University of Copenhagen, Denmark.

2 Danish Building Research Institute, Hørsholm, Denmark.

3 Cowiconsult, Consulting Engineers and Planners AS, Virum, Denmark.

4 The Danish Indoor Climate Study Group: S Gravesen: Allergologic laboratory; E Christophersen, J Kristensen, O Nielsen, PA Nielsen, ES OIsen and O Valbjørn: Danish Building Research Institute; V Clausen: Danish Illuminating Engineering Laboratory; L Mølhave: Institute of Hygiene, Aarhus; O Albrechtsen and PO Fanger: Laboratory of Heating and Air-conditioning, Technical University of Denmark; N Jonassen: Laboratory of Technical Physics, Technical University of Denmark; I Andersen, NO Breum, C Franck, P Laursen, P-A Lund, T Schneider, and P Wolkoff: National Institute of Occupational Health; F Gyntelberg and P Skov: Clinic of Occupational Medicine, Rigshospitalet.

Reprint requests to: Dr P Skov, SAS Occupational Health Department, PO Box 150, DK-2770 Kastrup, Denmark. headache, fatigue, and malaise were prevalent and differed significantly from one building to another without being explainable by the results of a determination of several components of indoor pollution $(3,4)$.

The purpose of the Danish town hall study, of which this investigation was a part, was to examine the influence of various indoor climate factors on the prevalence of the symptoms of the sick building syndrome. We have previously reported that factors such as sex, job category, work functions (handling of carbonless paper, photocopying, work at video display terminals), and psychosocial factors of work (dissatisfaction with superiors or colleagues and quantity of work inhibiting job satisfaction) were associated with work-related mucosal irritation and work-related general symptoms, but these factors could not account for the differences between the town halls as to the prevalence of the symptoms. It was also found that the building factor (ie, the indoor climate) was strongly associated with the prevalence of the symptoms (8). In this paper, the association between the measured indoor climate factors and work-related mucosal irritation and workrelated general symptoms has been described.

\section{Materials and methods}

\section{The buildings}

Participation in the study was requested of the municipalities of Copenhagen, Frederiksberg, and the County of Copenhagen, a total of 20 municipalities. Thirteen of them entered the study, three were excluded because comprehensive indoor climate studies had recently been carried out or were in progress, one an- 
swered too late to be included, and three did not want to participate. The town halls in the municipalities were selected as the study buildings. In one of the municipalities two buildings (number 120 and 121) were included.

Three of the study buildings had minor building construction differences (eg, type of ventilation). Each of these three was therefore divided into two sections on the basis of these differences, and only the sections in which indoor climate measurements were carried out were included in the multivariate analyses described in this paper.

The age of the buildings ranged from 1 to 80 (mean 18) years. Five buildings were situated in rural, four in urban, and five in residential areas. Six buildings had natural ventilation, and eight had central mechanical ventilation systems. Of these eight, five buildings had both supply and exhaust air systems, while three only had exhaust air systems.

Two of the supply air systems provided recirculation and two had humidifiers, of which, however, only one was in use. All of the buildings had windows which could be opened and radiator or convection heating. The floor area ranged from 1250 to 12900 (mean 4572) $\mathrm{m}^{2}$, and the number of employees in the buildings ranged from 84 to 419 (mean 207).

\section{Study population}

The study population of 4369 employees in the town halls, the 14 affiliated buildings, and various smaller buildings and rooms (with 47 employees only) received a questionnaire. Of these 3507 employees (2347 women, 1115 men, and 45 for whom sex was not stated) returned the questionnaire; 3181 were office workers. The other respondents worked as nurses, town hall officers, or chauffeurs or had jobs in other nonoffice or unknown job categories. The response rate ranged from 61 to 93 (mean 80 ) for the town halls and from 57 to 100 (mean 79) for the 14 affiliated buildings.

The reasons stated for not participating in the study were sick leave, maternity leave, vacation, and, in about $10 \%$ of the cases, unwillingness to participate. The distribution of participants by sex, age, years of office work, and job category has been described in a previous paper (8).

The analyses dealt with only 2369 office workers from the 14 study buildings in which indoor climate measurements were made.

\section{Questionnaire study}

The questionnaire included questions on the work, its type, previous and present diseases, presence of symptoms from the mucous membranes, presence of general symptoms, and the frequency and time variations of such symptoms. Questions about various other symptoms, complaints about the indoor climate (draft, low temperature, etc), family and housing conditions, exercise habits, and consumption of tobacco, alcohol, and other beverages were also included.

The possible categories of answers to the questions about individual symptoms were: "no," "yes, some times a year," "yes, some times a month," "yes, some times a week," and "yes, daily." Questions were also asked about variation in the degree of symptoms, for which the following categories of answers were employed: "yes, it improves at work," "yes, it improves on days off/during weekends or vacations," "no, it is always the same," and "don't know." If a particular symptom occurred some times a week or daily and improved on days off, the symptom was classified as work-related.

Besides single symptoms, the following two groups of work-related symptoms were included: (i) workrelated irritation of the mucous membranes (at least one of the work-related symptoms of irritation or dryness of the mucous membrane of the eyes, nose, or throat) and (ii) work-related general symptoms (at least one of the work-related symptoms of headache, abnormal fatigue, or malaise).

\section{Indoor climate measurements}

In each of the 14 study buildings one office was selected as representative of the majority of the offices in the building with respect to building materials, equipment, size, activity, and technical installations (including lighting). Clients did not have regular access to the rooms selected. Supplementary measurements of temperature, dust, and microorganisms in floor dust were made in other rooms. An engineer studied the technical specifications of the heating and ventilation system and estimated the ventilation rate. Except for a few factors, the measurements were performed on three consecutive days in each town hall during the period from 31 January to 3 May 1984. The results are shown in table 1.

\section{Thermal environment and relative humidity}

During 1.5 to $3 \mathrm{~d}$ air temperature and relative humidity were measured at table level with a Lambrecht thermohygrograph. Measurements of the air temperature were also made 0.1 and $1.1 \mathrm{~m}$ from the floor with a Blichfelt electronic thermometer with a thermocouple. Furthermore, the air temperature was registered in two other offices, and short-term measurements were made in about $20 \%$ of the offices - randomly selected in the building. A person-weighted air temperature was calculated, each measurement being entered with a weight corresponding to the number of persons in the office. The velocity of the air was checked with a smoke ampul and determined with a thermoanemometer if estimated to be more than $0.15 \mathrm{~m} / \mathrm{s}$. 


\section{Carbon dioxide}

The concentration of carbon dioxide was measured with an indicator tube (Dräger) in the morning and in the afternoon.

\section{Static electricity}

The static electrical charge of the persons in the office, including a member of the study group (the same member in all cases), was measured with an electrometer (Keithley 602) while the persons were walking to and fro.

\section{Formaldehyde}

The content of formaldehyde in the air was measured for $2 \mathrm{~h}$ with a spectrophotometer after absorption in acetyl acetone (Regeno field analyzer).

\section{Airborne dust}

The concentration of dust in the air was determined by use of a Dupont pump (P4000) and a membrane filter (Millipore FSLW, $37 \mathrm{~mm}$ ). The determination was made $1.1 \mathrm{~m}$ from the floor near a workplace in the middle of the office over a period of about $10 \mathrm{~h}$ during workhours, distributed on $2 \mathrm{~d}$. The sample volume was about $2.5 \mathrm{~m}^{3}$ of air. The filter holder was

Table 1. Indoor climate measurements in the 14 town halls. (cfu=colony-forming units)

\begin{tabular}{|c|c|c|}
\hline Measurement & Mean & Range \\
\hline Mean external temperature $(24 \mathrm{~h})\left({ }^{\circ} \mathrm{C}\right)$ & 2.4 & $11.4--1.2$ \\
\hline Sunshine hours, daily average (h) & 2.3 & $6.4-0$ \\
\hline Air temperature $\left({ }^{\circ} \mathrm{C}\right)$ & 22.7 & $24.1-20.5$ \\
\hline Person-weighted air temperature $\left({ }^{\circ} \mathrm{C}\right)$ & 23.0 & $24.4-22.0$ \\
\hline Temperature rise during a workday $\left({ }^{\circ} \mathrm{C}\right)$ & 2.5 & $8.0-1.0$ \\
\hline Vertical temperature gradient $\left({ }^{\circ} \mathrm{C} / \mathrm{m}\right)$ & 0.9 & $2.0-0.4$ \\
\hline Air velocity $(\mathrm{m} / \mathrm{s})$ & 0.15 & $0.20-<0.15$ \\
\hline Relative humidity $(\%)$ & 32 & $40-25$ \\
\hline Carbon dioxide (maximum) (\%) & 0.08 & $0.13-0.05$ \\
\hline Formaldehyde $\left(\mathrm{mg} / \mathrm{m}^{3}\right)$ & 0.04 & $0.08-0$ \\
\hline \multicolumn{3}{|l|}{ Static electricity } \\
\hline $\begin{array}{l}\text { Observer (kV) } \\
\text { Occupants (maximum) (kV) }\end{array}$ & $\begin{array}{l}1.4 \\
1.7\end{array}$ & $\begin{array}{l}4.8-0 \\
4.0-0\end{array}$ \\
\hline Airborne dust $\left(\mathrm{mg} / \mathrm{m}^{3}\right)$ & 0.201 & $0.382-0.086$ \\
\hline \multicolumn{3}{|l|}{ Dust particles } \\
\hline $\begin{array}{l}>0.5 \mu \mathrm{m}\left(1^{-1}\right) \\
>2.0 \mu \mathrm{m}\left(1^{-1}\right)\end{array}$ & $\begin{array}{l}48 \times 10^{3} \\
25 \times 10^{2}\end{array}$ & $\begin{array}{l}119 \times 10^{3}-19 \times 10^{3} \\
116 \times 10^{2}-8 \times 10^{2}\end{array}$ \\
\hline Airborne microfungi (cfu/m³) & 32 & $111-0$ \\
\hline Airborne bacteria $\left(\mathrm{cfu} / \mathrm{m}^{3}\right)$ & 574 & $2100-120$ \\
\hline Airborne actinomycetes $\left(\mathrm{cfu} / \mathrm{m}^{3}\right)$ & 4 & $15-0$ \\
\hline Vacuumed dust ${ }^{2}\left(g / 12 m^{2}\right)$ & 3.67 & $11.56-0.32$ \\
\hline Vacuumed dust ${ }^{\mathrm{b}}\left(\mathrm{g} / 12 \mathrm{~m}^{2}\right)$ & 6.14 & $17.04-0.66$ \\
\hline Macromolecular content in the dust $(\mathrm{mg} / \mathrm{g})$ & 1.53 & $5.24-0$ \\
\hline Microfungi in the dust ${ }^{a}$ (cfu/30 $\mathrm{mg}$ ) & 33 & $90-11$ \\
\hline Microfungi in the dust ${ }^{b}$ (cfu/ $30 \mathrm{mg}$ ) & 32 & $192-6$ \\
\hline Bacteria in the dust ${ }^{\mathrm{a}}$ (cfu/30 $\mathrm{mg}$ ) & 199 & $380-41$ \\
\hline Bacteria in the dust ${ }^{\mathrm{b}}$ (cfu/30 mg) & 296 & $680-160$ \\
\hline Man-made mineral fibers (MMMF) in the air (fibers $/ \mathrm{m}^{3}$ ) & 5 & $60-0$ \\
\hline \multicolumn{3}{|l|}{ Non-MMMF in the air } \\
\hline $\begin{array}{l}<3 \mu \mathrm{m}\left(\text { fibers } / \mathrm{m}^{3}\right) \\
>3 \mu \mathrm{m}\left(\text { fibers } / \mathrm{m}^{3}\right)\end{array}$ & $\begin{array}{r}33.2 \times 10^{3} \\
3.1 \times 10^{3}\end{array}$ & $\begin{array}{c}59.1 \times 10^{3}-18.5 \times 10^{3} \\
5.0 \times 10^{3}-0.7 \times 10^{3}\end{array}$ \\
\hline \multicolumn{3}{|l|}{ Volatile organic compounds } \\
\hline $\begin{array}{l}\text { Charcoalc }\left(\mathrm{mg} / \mathrm{m}^{3}\right) \\
\text { Tenax }^{d}\left(\mathrm{mg} / \mathrm{m}^{3}\right)\end{array}$ & $\begin{array}{r}1.56 \\
0.5\end{array}$ & $\begin{array}{c}2.63-0.43 \\
1.2-0.1\end{array}$ \\
\hline A-weighted equivalent noise level ( $d B$ ) & 56.7 & $60.3-51.3$ \\
\hline A-weighted background noise level (dB) & 36.2 & $44.1-28.2$ \\
\hline Reverberation time (s) & 0.41 & $1.05-0.28$ \\
\hline
\end{tabular}

a In the office where all the measurements were performed.

b In an office with a considerable load of clients during the day.

c Mean of readings in six buildings.

d Mean of readings in 13 buildings, in one building a level of $32 \mathrm{mg} / \mathrm{m}^{3}$ was found. 
turned downwards, and the air velocity at the intake was $1.25 \mathrm{~m} / \mathrm{s}$.

The determination was repeated over 1 to $2 \mathrm{~h}$ during the period from October to December 1984 in connection with the determination of mineral fibers with a sample volume of 1.7 to $3.4 \mathrm{~m}^{3}$. The number and size of the particles in the indoor air was measured with a Climet optic particle counter $1.1 \mathrm{~m}$ from the floor near a workplace in the middle of the office. The counting was made over 20 to $30 \mathrm{~min}$ in the afternoon.

\section{Dust on the floor}

In the study office and in an office with many daily clients, the amount of removable dust on the floor was determined from $12 \mathrm{~m}^{2}$ of the floor, which was vacuumed (Hoover S-1015-011) for 4 min towards the end of a workday. The concentration of macromolecular organic floor dust (MOD) was determined as described by Løwenstein (9).

\section{Microorganisms}

Airborne microorganisms were collected in the afternoon $1.1 \mathrm{~m}$ from the floor near a workplace in the middle of the office with a BIAP slit sampler. Samples were collected for the determination of microfungi, bacteria, and thermophilic actinomycetes (10). The microfungi were identified as to genus and, in some cases, as to species. The numbers of colony-forming units of microfungi, bacteria, and actinomycetes per $30 \mathrm{mg}$ of dust were determined.

\section{Airborne fibers}

Owing to errors in the first samplings, the concentration of airborne fibers was measured during the period from October to December 1984. The dust was collected with a Reciprotor vacuum unit (VABI) on a membrane filter (Millipore RAWP) in a 37-mm openfaced filter holder with its opening facing upwards and examined for man-made mineral fibers (MMMF) and other fibers by optic microscopy. The sample volume -1.7 to $3.4 \mathrm{~m}^{3}$ of air - was determined with a drygas meter (IGA-ACSMTC). The sampling was made near a workplace in the middle of the office during 1 to $2 \mathrm{~h}$ and with an air velocity at the intake of $1.25 \mathrm{~m} / \mathrm{s}(11)$.

\section{Fibers settled on surfaces}

Two special adhesive foils were pressed four or eight times against the surface of a table or shelf. The number and size distribution of the man-made mineral fibers per square centimeter were determined in a polarization microscope $(\times 500)$ with special equipment for projecting the image on a digitizer (11).

\section{Volatile organic compounds}

A known volume of air was sucked in through an adsorbent. The adsorbent Tenax was employed in all the buildings, charcoal in six. The samples were collected $1.1 \mathrm{~m}$ from the floor during 25 to $50 \mathrm{~min}$ with the Tenax adsorbent and during approximately $5 \mathrm{~h}$ with charcoal.

The adsorbed gases and vapors were analyzed with a gas chromatograph, and the results have been given as the total concentration of volatile organic components, the total concentration being based on pentadecane for Tenax and on toluene for charcoal.

\section{Lighting}

The general room illumination was measured with a luxmeter. An evaluation was made of the distribution of the luminance, the adequacy of the lamps, if any, the risk of annoying reflections, both at the work tables and at displays, if any, the amount of daylight, and the glare from the windows.

\section{Noise and time of reverberation}

Over $24 \mathrm{~h}$, the statistical distribution of the A-weighted sound pressure level was measured with a statistical noise analyzer and a microphone. The frequency distribution and the time of reverberation were measured with a one-third octave parallel analyzer via a microphone. In the town halls with mechanical ventilation systems, the frequency distribution was also measured under different work conditions for the system with no employees present in the office.

\section{Evaluation of materials}

The building materials and the materials used in the representative offices were recorded. On the basis of this information, a "fleece" factor and a "shelf" factor were calculated, the former being expressed as the area of all textile floor coverings, curtains, and seats divided by the volume of the room and the latter as the length of all open, filled shelves and cupboards divided by the volume of the room.

\section{Cleaning factor}

Data was collected on cleaning methods, materials, frequency, and the ability to carry out the cleaning, and a joint cleaning factor was scored and categorized as "very good," "good," "not so good," or "bad."

\section{Statistical methods}

The Spearman rank correlation coefficient was used to analyze the association between each of the indoor climate factors and between the indoor climate factors and the prevalence of symptoms.

The multifactorial effects on prevalence were analyzed in a logistic regression model according to Bres- 
low \& Day (12). With this model the probability of response is related to a set of regression variables $\mathrm{x}=\left(\mathrm{x}_{1}, \ldots \ldots, \mathrm{x}_{\mathrm{p}}\right)$ via the following equation:

$$
P(x)=\left[\exp \left(\alpha+\Sigma \beta_{j} x_{j}\right] /\left[1+\exp \left(\alpha+\Sigma \beta_{j} x_{j}\right)\right] .\right.
$$

In this case, the probability for each individual developing the symptom was expressed as a function of the characteristics of that same person and of the indoor climate factors measured in the building where the person was situated.

The betas were parameters to be estimated. The interpretation of these parameters was made via the odds ratio (OR). For individuals with characteristics $\mathrm{x}$ and $\mathrm{X}^{*}$, respectively, the odds ratio was:

$$
\exp \left[\Sigma \beta_{j}\left(x_{j}-x_{j}^{*}\right)\right] .
$$

The $95 \%$ confidence intervals of the odds ratios were estimated from the corresponding confidence interval of $\beta[\beta \pm 1.96 \mathrm{SD}(\beta)]$.

In a previous paper the influence of personal characteristics, job-related factors, and psychosocial factors has been reported (8). The buildings were analyzed as a categorical variable (highly significant). In this paper the categorical variable was replaced by the measurements of the indoor climate factors in the town halls.

The indoor climate factors were divided into three groups, one including factors which, hypothetically, could produce a direct effect (eg, airborne dust and temperature), another consisting of factors which, hypothetically, could produce an indirect effect (eg, number of workplaces and area of fleecy material), and the last consisting of factors which were considered characteristics of the office and building (eg, floor covering and age of the building).

Due to the large number of indoor climate factors investigated and the limited sample of buildings, the estimation was carried out with both a forward selection procedure and a modified backward elimination procedure. Each group of factors was analyzed separately, and the significant factors were then analyzed together. The level of significance used in the analysis was $\mathrm{P}<0.05$.

In all cases the main effect of the personal characteristics, job-related factors, and psychosocial factors (8) was retained in the analysis.

Several of the indoor climate factors were segregated into two or three groups and were analyzed as continuous variables as well.

\section{Results}

\section{Correlation between indoor climate factors and symptoms}

In table 2 the indoor climate factors are shown which significantly correlated either with mucosal irritation or with general symptoms. Several of these factors were also mutually correlated as shown in table 3 .

Other factors, such as office volume or area per workplace, ventilation rate, relative humidity, temperature, carbon dioxide, formaldehyde, static electricity, volatile organic compounds, man-made mineral fibers in the air or on surfaces, etc, did not significantly correlate with symptom prevalence; yet some of them were included in the multivariate analyses due to a hypothesis of a possible effect on the symptoms.

\section{Mucosal irritation}

All the indoor climate factors shown in table 2 and a couple of other factors were significantly associated with mucosal irritation in the multivariate analyses, when added separately to the logistic regression model containing the main effects of personal characteristics, job-related factors, and psychosocial factors. The macromolecular organic part of the floor dust showed the strongest association $(\mathrm{P}<0.0001)$.

Depending on the order in which the three groups of indoor climate factors were introduced into the multivariate analyses and whether a forward selection or a backward elimination procedure was used, five different models were found (table 4). One of these models contained a linear association with macromolecular organic dust supplemented by an association with the amount of floor dust. However, the estimated OR did not increase as the total amount of

Table 2. Correlation between indoor climate factors and symptom prevalence. ${ }^{a}$ (NS $=$ not significant, $c f u=$ colony-forming

\begin{tabular}{|c|c|c|c|}
\hline Indoor climate factors & $\begin{array}{l}\text { Mucosal } \\
\text { irritation }\end{array}$ & $\begin{array}{l}\text { Gene } \\
\text { symptc }\end{array}$ & $\begin{array}{l}\text { eral } \\
\text { oms }\end{array}$ \\
\hline Age of the building (years) & -0.57 & -0.30 & NS \\
\hline Sunscreen of windows (yes/no) & -0.57 & -0.63 & \\
\hline $\begin{array}{l}\text { Ventilation type (supply air } \\
\text { systems/other) }\end{array}$ & $0.35 \mathrm{NS}$ & 0.47 & \\
\hline Area of the office $\left(\mathrm{m}^{2}\right)$ & 0.54 & 0.76 & \\
\hline Volume of the office $\left(\mathrm{m}^{3}\right)$ & $0.30 \mathrm{NS}$ & 0.55 & \\
\hline $\begin{array}{l}\text { Number of workplaces } \\
\text { in the office }\end{array}$ & 0.55 & 0.82 & \\
\hline Air velocity $(\mathrm{m} / \mathrm{s})$ & 0.54 & 0.76 & \\
\hline Dust particles $>10 \mu \mathrm{m}\left(1^{\cdots 1}\right)$ & $-0.35 \mathrm{NS}$ & -0.49 & \\
\hline Airborne bacteria (cfu/m³) & $0.42 \mathrm{NS}$ & 0.51 & \\
\hline Floor dust $\left(\mathrm{g} / 12 \mathrm{~m}^{2}\right)$ & 0.52 & 0.43 & NS \\
\hline Organic floor dust (mg/g) & 0.50 & 0.64 & \\
\hline $\begin{array}{l}\text { A-weighted equivalent noise } \\
\text { level (dB) }\end{array}$ & $-0.27 \mathrm{NS}$ & -0.55 & \\
\hline Reverberation time (s) & -0.69 & -0.64 & \\
\hline Fleece factor $\left(\mathrm{m}^{2} / \mathrm{m}^{3}\right)$ & 0.64 & 0.50 & \\
\hline Shelf factor $\left(\mathrm{m} / \mathrm{m}^{3}\right)$ & 0.63 & 0.67 & \\
\hline $\begin{array}{l}\text { Floor covering } \\
\text { (bare floor/needle-felt carpet/ } \\
\text { loop-woven carpet) }\end{array}$ & 0.67 & 0.35 & NS \\
\hline
\end{tabular}
units)

a Included are those indoor climate factors associated with either mucosal irritation or general symptoms with a significant $(P<0.05)$ Spearman's rank correlation coefficient. 
Table 3. Correlation between the following indoor climate factors: age of the building (A), sunscreen (B), ventilation type (C), area of the office (D), volume of the office (E), number of workplaces in the office $(F)$, air velocity $(G)$, dust particles $>10 \mu \mathrm{m}$ $(\mathrm{H})$, airborne bacteria $(\mathrm{I})$, floor dust $(\mathrm{J})$, organic floor dust $(\mathrm{K})$, noise level $(\mathrm{L})$, reverberation time $(\mathrm{M})$, fleece factor $(\mathrm{N})$, shelf factor $(\mathrm{O})$, and floor covering $(\mathrm{P})$.

\begin{tabular}{|c|c|c|c|c|c|c|c|c|c|c|c|c|c|c|c|}
\hline & A & $B$ & $c$ & D & $E$ & $F$ & $\mathrm{G}$ & $\mathrm{H}$ & 1 & $J$ & $K$ & $L$ & M & $N$ & 0 \\
\hline $\begin{array}{l}A \\
B \\
C \\
D \\
E \\
F \\
G \\
H \\
I \\
J \\
K \\
L \\
M \\
N \\
O \\
P\end{array}$ & $\begin{array}{r}0.66 \\
-0.05 \\
-0.25 \\
0.17 \\
-0.06 \\
-0.22 \\
0.06 \\
-0.34 \\
-0.30 \\
-0.26 \\
-0.14 \\
0.57 \\
-0.49 \\
-0.71 \\
-0.84\end{array}$ & $\begin{array}{r}-0.47 \\
-0.62 \\
0.00 \\
-0.44 \\
-0.35 \\
0.35 \\
-0.37 \\
-0.20 \\
-0.30 \\
0.12 \\
0.70 \\
-0.35 \\
-0.47 \\
-0.43\end{array}$ & $\begin{array}{r}-0.44 \\
0.30 \\
0.39 \\
0.46 \\
-0.10 \\
0.12 \\
0.36 \\
0.57 \\
-0.61 \\
-0.28 \\
0.26 \\
0.13 \\
0.03\end{array}$ & $\begin{array}{r}0.84 \\
0.93 \\
0.66 \\
-0.51 \\
0.62 \\
0.21 \\
0.59 \\
-0.54 \\
-0.30 \\
0.38 \\
0.41 \\
0.06\end{array}$ & $\begin{array}{r}0.89 \\
0.56 \\
-0.32 \\
0.50 \\
0.18 \\
0.58 \\
-0.57 \\
0.02 \\
0.28 \\
0.15 \\
-0.21\end{array}$ & $\begin{array}{r}0.72 \\
-0.49 \\
0.54 \\
0.20 \\
0.58 \\
-0.58 \\
-0.34 \\
0.41 \\
0.38 \\
-0.04\end{array}$ & $\begin{array}{r}-0.38 \\
0.29 \\
0.24 \\
0.52 \\
-0.64 \\
0.37 \\
0.33 \\
0.69 \\
0.08\end{array}$ & $\begin{array}{r}0.04 \\
0.02 \\
-0.02 \\
0.22 \\
0.03 \\
-0.01 \\
-0.24 \\
0.06\end{array}$ & $\begin{array}{r}0.22 \\
0.50 \\
-0.02 \\
-0.33 \\
0.44 \\
0.33 \\
0.37\end{array}$ & $\begin{array}{r}0.67 \\
-0.18 \\
-0.47 \\
0.65 \\
0.13 \\
0.61\end{array}$ & $\begin{array}{r}-0.54 \\
-0.30 \\
0.80 \\
0.41 \\
0.41\end{array}$ & $\begin{array}{r}0.08 \\
-0.04 \\
-0.30 \\
0.21\end{array}$ & $\begin{array}{l}-0.46 \\
-0.48 \\
-0.57\end{array}$ & $\begin{array}{l}0.42 \\
0.64\end{array}$ & 0.54 \\
\hline
\end{tabular}

a Included are those indoor climate factors associated either with mucosal irritation or with general symptoms with a significant $(P<0.05)$ Spearman's rank correlation coefficient.

Table 4. Odds ratios for mucosal irritation in logistic regression models containing the main effect of personal characteristics, job-related factors, and psychosocial factors. (MOD = macromolecular organic part of the floor dust, $\mathrm{OR}=$ odds ratio, $95 \% \mathrm{Cl}=95 \%$ confidence interval)

\begin{tabular}{|c|c|c|}
\hline Indoor climate factors & OR & $95 \% \mathrm{Cl}$ \\
\hline \multicolumn{3}{|l|}{ Model I } \\
\hline \multicolumn{3}{|l|}{ Floor dust $\left(g / 12 \mathrm{~m}^{2}\right)$} \\
\hline $\begin{array}{r}<2 \\
2-4 \\
>4\end{array}$ & $\begin{array}{l}1 \\
1.93 \\
1.59\end{array}$ & $\begin{array}{l}1.44-2.59 \\
1.17-2.16\end{array}$ \\
\hline MOD (mg/g) per mg & 1.11 & $1.03-1.20$ \\
\hline \multicolumn{3}{|l|}{ Model 2} \\
\hline MOD (mg/g) per mg & 1.13 & $1.04-1.22$ \\
\hline \multicolumn{3}{|l|}{ Floor covering } \\
\hline $\begin{array}{l}\text { Bare floor } \\
\text { Needle-felt carpet } \\
\text { Loop-woven carpet }\end{array}$ & $\begin{array}{l}1 \\
1.52 \\
2.03\end{array}$ & $\begin{array}{l}1.12-2.07 \\
1.51-2.72\end{array}$ \\
\hline \multicolumn{3}{|l|}{ Model 3} \\
\hline $\begin{array}{l}\text { Area }\left(m^{2}\right) \text { of the office } \\
\text { per } 10 \mathrm{~m}^{2}\end{array}$ & 1.06 & $1.03-1.09$ \\
\hline \multicolumn{3}{|l|}{ Floor covering } \\
\hline $\begin{array}{l}\text { Bare floor } \\
\text { Needle-felt carpet } \\
\text { Loop-woven carpet }\end{array}$ & $\begin{array}{l}1 \\
1.53 \\
2.38\end{array}$ & $\begin{array}{r}1.15-2.04 \\
1.83-3.09\end{array}$ \\
\hline \multicolumn{3}{|l|}{ Model 4} \\
\hline $\begin{array}{l}\text { Shelf factor }\left(\mathrm{m} / \mathrm{m}^{3}\right) \\
\text { per } 1 \mathrm{~m} / \mathrm{m}^{3}\end{array}$ & 1.52 & $1.12-2.06$ \\
\hline \multicolumn{3}{|l|}{ Floor covering } \\
\hline $\begin{array}{l}\text { Bare floor } \\
\text { Needle-felt carpet } \\
\text { Loop-woven carpet }\end{array}$ & $\begin{array}{l}1 \\
1.95 \\
2.03\end{array}$ & $\begin{array}{r}1.51-2.50 \\
1.50-2.74\end{array}$ \\
\hline \multicolumn{3}{|l|}{ Model 5} \\
\hline $\begin{array}{l}\text { Age of the building } \\
\text { per } 10 \text { years }\end{array}$ & 0.93 & $0.90-0.95$ \\
\hline \multicolumn{3}{|l|}{ Ventilation type } \\
\hline $\begin{array}{l}\text { Natural/exhaust only } \\
\text { Supply air system }\end{array}$ & 1.41 & $1.13-1.77$ \\
\hline \multicolumn{3}{|l|}{ Floor covering } \\
\hline $\begin{array}{l}\text { Bare floor } \\
\text { Needle-felt carpet } \\
\text { Loop-woven carpet }\end{array}$ & $\begin{array}{l}1 \\
1.73 \\
2.05\end{array}$ & $\begin{array}{l}1.32-2.26 \\
1.53-2.76\end{array}$ \\
\hline
\end{tabular}

dust increased. In three of the models floor covering had a significant effect and was supplemented with a linear effect from macromolecular organic dust, area of the office, or the shelf factor. In the fourth model floor covering was supplemented with the age of the building and type of ventilation. The estimated OR values for floor covering were very much alike in all four models. The OR increased when the floor was carpeted, especially with loop-woven carpets (OR approximately 2). The OR decreased as the age of the building increased; for example, the OR was 1.77 for a one-year-old building when it was compared with an 80 -year-old building.

Buildings with supply air systems had a higher estimated OR (1.85) than buildings naturally ventilated or mechanically ventilated and employing exhaust only.

\section{General symptoms}

As for mucosal irritation all the factors shown in table 2 and a couple of other indoor climate factors were significantly associated with general symptoms when added separately to the logistic regression model. The most significant factor was the number of workplaces in the office.

Four different models were found in the multivariate analyses (table 5).

The fleece factor had a significant effect, together with volume of the office, number of workplaces in the office, or noise level (not shown). The estimated $O R$ values increased as the area of fleecy material in the office, the volume of the office, or the number of workplaces in the office increased, but decreased as the noise level increased - in contrast to what might have been expected.

In the model with a linear association to the concentration of macromolecular organic dust, cor- 
responding to an OR of 1.73 for a difference of $5 \mathrm{mg} / \mathrm{g}$ of macromolecular organic dust, there was also an effect for person-weighted temperature.

The OR decreased as the age of the building increased, and mechanically ventilated buildings with supply air systems had a higher OR than naturally ventilated or mechanically ventilated buildings with exhaust only.

\section{Discussion}

In contrast to previous studies on the sick building syndrome, this study included both a large population and several indoor climate factors measured in many buildings. In addition, some new indoor climate factors, such as the fleece factor and the shelf factor, were measured.

However, one of the main problems concerning the used methodology was that the measurements of most of the indoor climate factors were made in one office in each building over a short period of time. It is therefore natural to ask how representative these measurements are of the indoor climate in the whole building throughout the year. Actually, a one-year follow-up study of three of the buildings included in this study showed that most of the indoor climate factors did not change much from one year to another, but some factors varied from place to place within the building and during a workday - this variation was greater or equivalent to the variation between the buildings (13).

Selection bias and information bias were possible problems in this study and their occurrence cannot be completely ruled out. However, the response rate was not associated with the prevalence of work-related symptoms in the buildings, and the study was introduced to the employees as a general study of the indoor climate with no emphasis on single indoor climate factors. In general, the risk factors found in this study were not regarded as possible causes of the symptoms. In fact, carpets, for example, were, and still are, considered to give an office a cozy atmosphere and a good acoustic environment.

Discussions among the employees concerning the indoor climate could affect the prevalence of reported symptoms, but for a selected sample of the population we found that there was a good correlation between objective eye signs and reported eye irritation $(14,15)$.

The "healthy worker effect" is not likely to have been of importance as the symptoms would have made only a few employees leave their jobs.

Passive smoking was not considered in the analyses. However, the proportion of smokers was almost the same in all the buildings, and less than $20 \%$ of the employees were annoyed by tobacco smoke in the offices.
Table 5. Odds ratios for general symptoms obtained from logistic regression models containing the main effect of personal characteristics, job-related factors, and psychosocial factors. (MOD = macromolecular organic part of the floor dust, $\mathrm{OR}=$ odds ratio, $95 \% \mathrm{Cl}=95 \%$ confidence interval)

\begin{tabular}{|c|c|c|}
\hline Indoor climate factors & OR & $95 \% \mathrm{Cl}$ \\
\hline \multicolumn{3}{|l|}{ Model 1} \\
\hline $\begin{array}{l}\text { Volume of office }\left(\mathrm{m}^{3}\right) \\
\text { per } 100 \mathrm{~m}^{3}\end{array}$ & 1.25 & $1.19-1.32$ \\
\hline $\begin{array}{l}\text { Fleece factor }\left(\mathrm{m}^{2} / \mathrm{m}^{3}\right) \\
\text { per } 1 \mathrm{~m}^{2} / \mathrm{m}^{3}\end{array}$ & 1.70 & $1.49-1.93$ \\
\hline \multicolumn{3}{|l|}{ Model 2} \\
\hline $\begin{array}{l}\text { Number of workplaces } \\
\text { in the office } \\
\text { per workplace }\end{array}$ & 1.05 & $1.04-1.07$ \\
\hline $\begin{array}{l}\text { Fleece factor }\left(\mathrm{m}^{2} / \mathrm{m}^{3}\right) \\
\text { per } 1 \mathrm{~m}^{2} / \mathrm{m}^{3}\end{array}$ & 1.50 & $1.30-1.73$ \\
\hline \multicolumn{3}{|l|}{ Model 3} \\
\hline MOD $(\mathrm{mg} / \mathrm{g})$ per $\mathrm{mg}$ & 1.11 & $1.07-1.16$ \\
\hline \multicolumn{3}{|c|}{ Person-weighted temperature } \\
\hline $\begin{array}{l}21.0-22.9 \\
23.0-23.9 \\
>24.0\end{array}$ & $\begin{array}{l}1 \\
1.62 \\
0.94\end{array}$ & $\begin{array}{l}1.40-1.87 \\
0.76-1.17\end{array}$ \\
\hline \multicolumn{3}{|l|}{ Model 4} \\
\hline $\begin{array}{l}\text { Age of the building } \\
\text { per } 10 \text { years }\end{array}$ & 0.91 & $0.89-0.93$ \\
\hline \multicolumn{3}{|l|}{ Ventilation type } \\
\hline $\begin{array}{l}\text { Natural/exhaust only } \\
\text { Supply air system }\end{array}$ & $\begin{array}{l}1 \\
1.85\end{array}$ & $1.67-2.05$ \\
\hline
\end{tabular}

As shown in table 3, several of the indoor climate factors had a significant association with either workrelated mucosal irritation or work-related general symptoms. For some of the factors it is hard to believe that they can cause the symptoms reported. Likewise some of the associations were contrary to what had been expected - for example, there was a decreasing prevalence of work-related symptoms with an increasing concentration of airborne dust. It was also found - but has no meaning - that a short reverberation time gives a higher prevalence of work-related mucosal irritation or work-related general symptoms.

Mass significance may explain such findings, but also the fact that many of the factors were intercorrelated must be considered - some factors were correlated in a way that could be expected as, for example, floor covering and reverberation time.

Due to the limited number of buildings and the intercorrelation between the aforementioned factors, it was not possible to identify a single statistical model for each of the work-related groups in the multivariate analyses even though the models that were found were closely related.

Carpets were identified as one of the risk factors for work-related mucosal irritation in four of the five models, and macromolecular organic dust appeared in two of the models. Carpets and dust in carpets, especially the organic part of the dust, have previously been found to be associated with the sick building syn- 
drome (16) and with an increasing severity of asthma in schoolchildren (17). It has been claimed that needlefelt carpets give more indoor climate problems than other carpets (18), but this was not the case in our study, where the highest prevalence of work-related mucosal irritation was found in buildings with loopwoven carpets.

Total floor dust closely correlated with floor covering. The smallest amount of floor dust was found in offices with bare floors, while most floor dust was found in needle-felt carpets. However, the highest prevalence of work-related mucosal irritation was seen in the middle category of total floor dust $(2-4 \mathrm{~g} /$ $12 \mathrm{~m}^{2}$ ) and likewise for loop-woven carpets, and this finding disfavors total floor dust as a risk factor. Furthermore, the relation between the total of vacuumed dust and the dust deposited in the carpets was not known and may depend on the structure of the carpet.

The risk of work-related mucosal irritation grew with the area of the office. The volume of the office and the number of workplaces, which of course closely correlated with each other and with the area of the office, were identified as risk factors for work-related general symptoms. Area per employee had no effect on the prevalence and therefore indicated that the size of the office and the number of persons in the office were the most important factors - presumably because of more disturbance and activity, the latter giving rise to more pollution in the air during the day.

The shelf factor was identified as a risk factor for work-related mucosal irritation, and the fleece factor proved to be a risk factor for work-related general symptoms. Fleecy surfaces, paper, and cardboard may accumulate various pollutants that can be emitted due either to activity in the room or to changes in temperature and humidity (19).

In accordance with other epidemiologic studies (2, 3,7 ), the type of ventilation in the building seemed to be a risk factor for both work-related mucosal irritation and work-related general symptoms.

Judged from the concentration of carbon dioxide in the indoor air, the buildings were sufficiently ventilated regarding bioeffluents, but, nevertheless, a substantial proportion of the occupants complained of stuffy air (8). In accordance with the results of Fanger (19), this finding indicates that the number of occupants present in the office is not the only factor influencing perceived air quality.

The town halls and their employees were chosen because we wanted to examine a uniform population with equal socioeconomic status and type of work, but exposed to different indoor climate conditions. Greater Copenhagen was chosen because the town halls have been built successively during the growth of that area in this century, and different types of construction and building materials have been employed. This assumption is supported by the fact that the age of the building was associated with both work-related mucosal irritation and work-related general symptoms. It is there- fore interesting to note the close correlation between age of the building and the type of floor covering.

Except for macromolecular organic dust, floor dust, and temperature, of which the results for macromolecular organic dust were the most consistent, the identified risk factors were characterized by being characteristics of the office or the building, easily recognizable by simple inspection. The characteristics of the selected offices are probably reasonably representative for other offices in the town halls; furthermore, these office and building characteristics are presumably more constant over time (weeks to years) than the other indoor climate factors.

The effect of air temperature was not consistent, as the OR for the highest interval was 0.94 . However, there was only one building with a person-weighted temperature in that interval $\left(>24^{\circ} \mathrm{C}\right)$. Still, we believe that a high indoor air temperature is a risk factor for work-related general symptoms.

It is interesting to note that airborne dust was not correlated either with symptom prevalence or with floor dust or macromolecular organic dust. It may be that the organic part of the dust is the most important, but there were no available methods for measuring this factor in the air.

The results of this study do not exclude the possibility that traditionally measured indoor climate factors have an influence on the prevalence of workrelated mucosal irritation and work-related general symptoms, but the majority of these factors only had a small variation between the town halls, and their influence, if any, could therefore not be estimated. The indoor climate factors were mainly at levels normally considered acceptable $(20,21)$ and in accordance with most indoor climate studies $(3,4)$ even where high prevalences of symptoms occur. One must therefore consider whether the prevailing methods of measuring the indoor climate give a sufficient description of the relevant exposure.

\section{Concluding remarks}

The results of this study showed that the concentration of macromolecular organic dust, floor covering, the number of workplaces in an office, the age of a building, the type of ventilation, and two easily recognizable indoor climate factors, the shelf factor and the fleece factor, are important factors associated with the occurrence of the sick building syndrome.

\section{Acknowledgments}

This work was supported by grants from the Rockwool Foundation, the Scandinavian Tobacco Company, Wiggins Teape, the Health Foundation, and the Working Environment Foundation. 


\section{References}

1. World Health Organization. Indoor air pollutants: exposure and health effects. Copenhagen: WHO Regional Office for Europe, 1983. (EURO reports and studies; no 78.)

2. Finnegan MJ, Pickering CAC, Burge PS. The sick building syndrome: prevalence studies. Br Med J 1984;289: 1573-5.

3. Robertson AS, Burge PS, Hedge A, et al. Comparison of health problems related to work and environmental measurements in two office buildings with different ventilations systems. Br Med J 1985;291:373-6.

4. Turiel I, Hollowel CD, Biksch RR, Rudy JV, Young RA, Coye MJ. The effects of reduced ventilation on indoor air quality in an office building. Atmos Environ 1983; $17: 51-64$.

5. McDonald JC, Arhirii M, Armstrong B, et al. Building illness in a large office complex. In: Walkinshaw DS, ed. Proceedings: indoor air quality in cold climates: hazards and abatement measures. Ottawa: Air Pollution Control Association, 1985:7-22.

6. Taylor PR, Dell'Acqua BJ, Baptiste MS, Hwang HL, Sovik RA. Illness in an office building with limited fresh air access. J Environ Health 1984;47(1):24-7.

7. Burge PS, Hedge A, Wilson S, Bass JH, Robertson A. Sick building syndrome: a study of 4373 office workers. Ann Occup Hyg 1987;31(4):493-504.

8. Skov P, Valbjørn O, Pedersen BV, the Danish Indoor Climate Study Group. Influence of personal characteristics, job-related factors and psychosocial factors on the sick building syndrome. Scand J Work Environ Health 1989;15:286-95.

9. Løwenstein H. Timothypollen allergens. Allergy 1980; 35:188-91.

10. Gravesen S, Larsen L, Skov P. Aerobiology of schools and public institutions - part of a study. Ecol Dis 1985;2:241-3.

11. Schneider T. Man-made mineral fibers and other fibers in the air and in settled dust. Environ Int 1986;12:61-5.
12. Breslow NE, Day NE. Statistical methods in cancer research; vol I (The analysis of case-control studies). Lyon: International Agency for Research on Cancer, 1980. (IARC scientific publications; no 32.)

13. Skov $P$, Valbjørn $O$, Gyntelberg F, the Danish Indoor Climate Study Group. Rådhusundersøgelsen - Indeklima i kontorer [The Danish town hall study]. Copenhagen: Arbejdsmiljøfondets forskningsrapporter, 1989. (English summary.)

14. Franck C. Eye Symptoms and signs in buildings with indoor climate problems (office eye syndrome). Acta Ophthalmol 1986;64:306-11.

15. Franck C, Skov P, the Danish Indoor Climate Study Group. Foam at inner eye canthus in office workers compared with an average Danish population as control group. Acta Ophthalmol 1989;67:61-8.

16. Nexø E, Skov P, Gravesen S. Extreme fatigue and malaise - a syndrome caused by malcleaned wall-to-wall carpets? Ecol Dis 1985;2:415-8.

17. Bach E, Hansen L, Ibsen KK, Østerballe O. Skolebørn med astma. Symptomernes afhængighed af miljøet. Tæppebelægning i skolerne [Asthma in school children]. Copenhagen: Sundhedsstyrelsens Hygiejnemeddelelser 1984;5. (English summary.)

18. Gravesen S, Larsen L, Gyntelberg F, Skov P. Demonstration of microorganisms and dust in schools and offices. Allergy 1986;41:520-5.

19. Fanger PO. Introduction of the olf and decipol units to quantify air pollution perceived by humans indoors and outdoors. Energy Build 1988;12;1:1-6.

20. Skov P, Valbjørn O, the Danish Indoor Climate Study Group. The sick building syndrome in the office environment: the Danish town hall study. Environ Int 1987; 13:339-49.

21. Nordiska Kommittén för Byggbestemmelser. Indoor climate. Stockholm: Statens Planverk, 1981. (NKB-report; no 41.)

Received for publication: 9 January 1990 